\title{
The Uses of Various Nanoparticles in Organic Synthesis: A Review
}

\author{
Khaturia $\mathrm{S}^{1}$, Chahar $\mathrm{M}^{2 *}$, Sachdeva $\mathrm{H}^{3}$, Sangeeta ${ }^{1}$, Mahto $\mathrm{CB}^{2}$ \\ ${ }^{1}$ Department of Chemistry, School of Sciences, Mody University of Science and Technology, Laxmangarh (Sikar), Rajasthan, India; ${ }^{2}$ Department of \\ Chemistry, Nalanda College of Engineering, Chandi, Nalanda, Bihar, India; ${ }^{3}$ Department of Chemistry, University of Rajasthan, Jaipur, India
}

\begin{abstract}
Nanoparticles have been widely applied in different areas including, medicine, sensor and catalysis. In our study we have concentrated our work towards the application of the metal nanoparticles in the field of catalysis. Several reports has been found on wide range of application of various supported metal nanoparticles in catalysis including $\mathrm{Au}, \mathrm{Ag}, \mathrm{Pt}, \mathrm{Cu}, \mathrm{Cd}, \mathrm{Ni}$ etc. metals in the form of reduced metals and in compounds forms as heterogeneous catalysis. Nanoparticles have potential for improving the efficiency, selectivity and yield of catalytic processes. Higher selectivity of the nanoparticles towards reaction proceeds through less waste and fewer impurities which could lead to safer technique and reduced environmental impact. In this review we have focused on the developments in new types of green nanocatalysts as well as developments in green catalytic reactions.
\end{abstract}

Keywords: Nanoparticles; Nanocatalysts; Organic synthesis; Green Nanocatalysts; Green reactions; Nanotechnology.

\section{INTRODUCTION}

The last decade has witnessed enormous development in the field of nanoscience and nanotechnology. Several reports show the amazing level of the performance of nanoparticles as catalysts in terms of selectivity, reactivity and improved yields of products. In addition, the high surface-to-volume ratio of nanoparticles provides a larger number of active sites per unit area, in comparison with their heterogeneous counter sites [1,2]. In this review, we focus on green nanocatalysts as well as industrially important green reactions. This article has two parts. The first part involves green nanocatalysts and the second part involves green reactions.

\section{SYNTHESIS OF VARIOUS NANOPARTICLES}

Various nanoparticles are shown in Figure 1 and Schemes 1-53 in Tables 1-15.

\section{Calcium oxide nanoparticles}

Among various nanoparticles, calcium oxide nanoparticles have

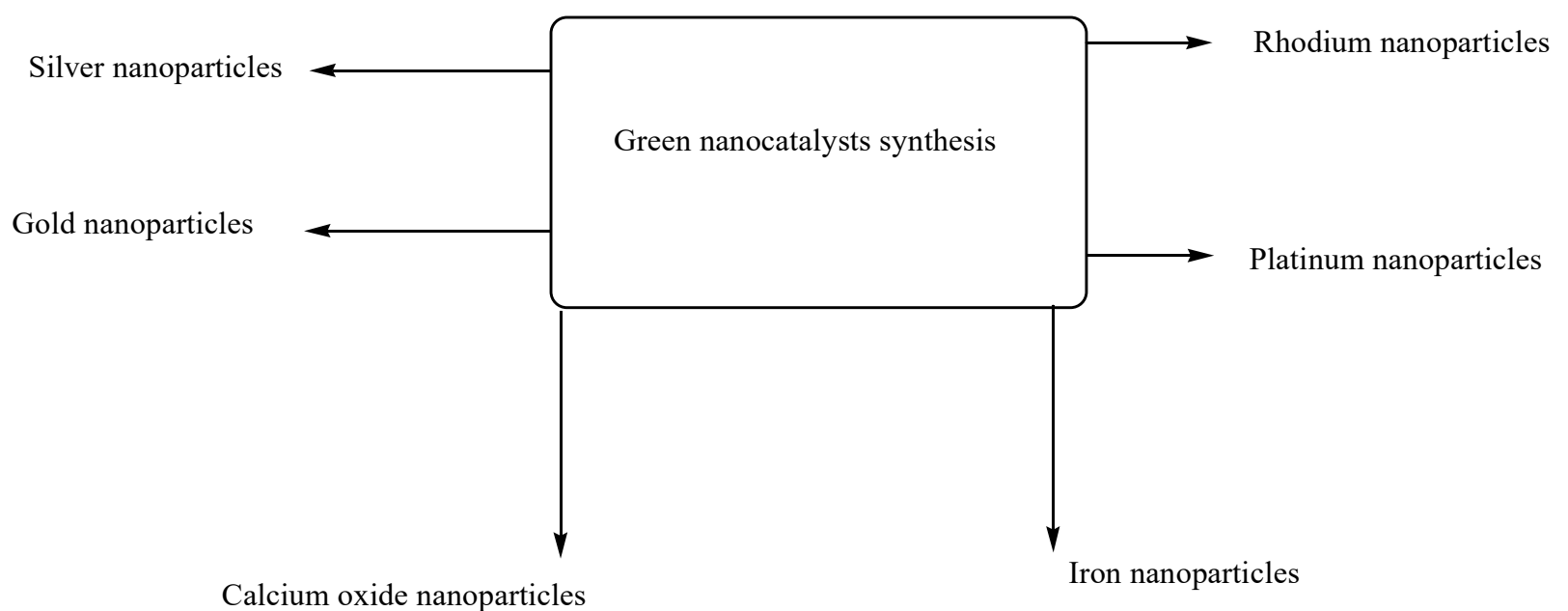

Figure 1: Various Green Nanocatalysts.

"Correspondence to: Mamta Chahar, Department of Chemistry, Nalanda College of Engineering, Chandi, Nalanda, Bihar, India, Tel: 7737075718; E-mail: mamtachahariitd@gmail.com

Received: February 10, 2020; Accepted: April 17, 2020; Published: April 24, 2020

Citation: Khaturia S, Chahar M, Sachdeva H, Sangeeta, Mahto CB (2020) A Review: The Uses of Various Nanoparticles in Organic Synthesis. J Nanomed Nanotech. 11:543. doi: 10.35248/2157-7439.20.11.543

Copyright: $@ 2020$ Khaturia S, et al. This is an open-access article distributed under the terms of the Creative Commons Attribution License, which permits unrestricted use, distribution, and reproduction in any medium, provided the original author and source are credited. 
Table 1: Reduction Reactions.

S. No. Reference No. Reaction

SCHEME 2: Reduction of Methylene Blue dye
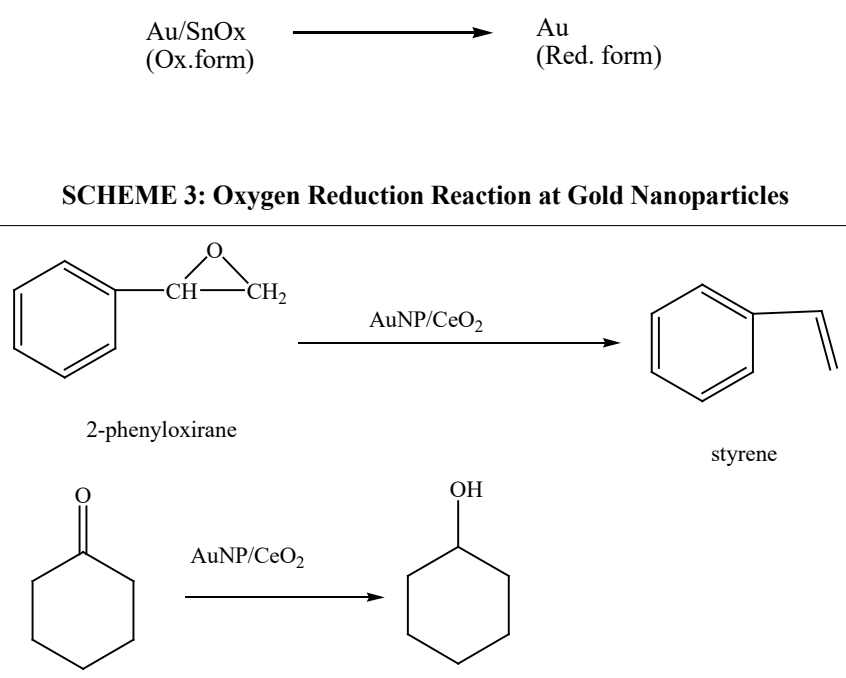

SCHEME 4: (i) Synthesis of styrene from 2-phenyl oxirane (ii) Synthesis of cyclohexanol from cyclohexanone

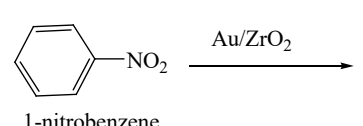

1-nitrobenzene

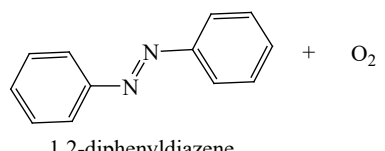

1,2-diphenyldiazene

SCHEME 6: Synthesis of 1,2-diphenyldiazine from nitrobenzene 
Table 2: Oxidation reactions.

S. No. Reference No.

Reaction

Nano particles

$\begin{array}{lll}\text { S. No. Reference No. Reaction } & \text {. } \\ 1 . & 92\end{array}$

SCHEME 8: Synthesis of benzaldehyde by phenyl methanol

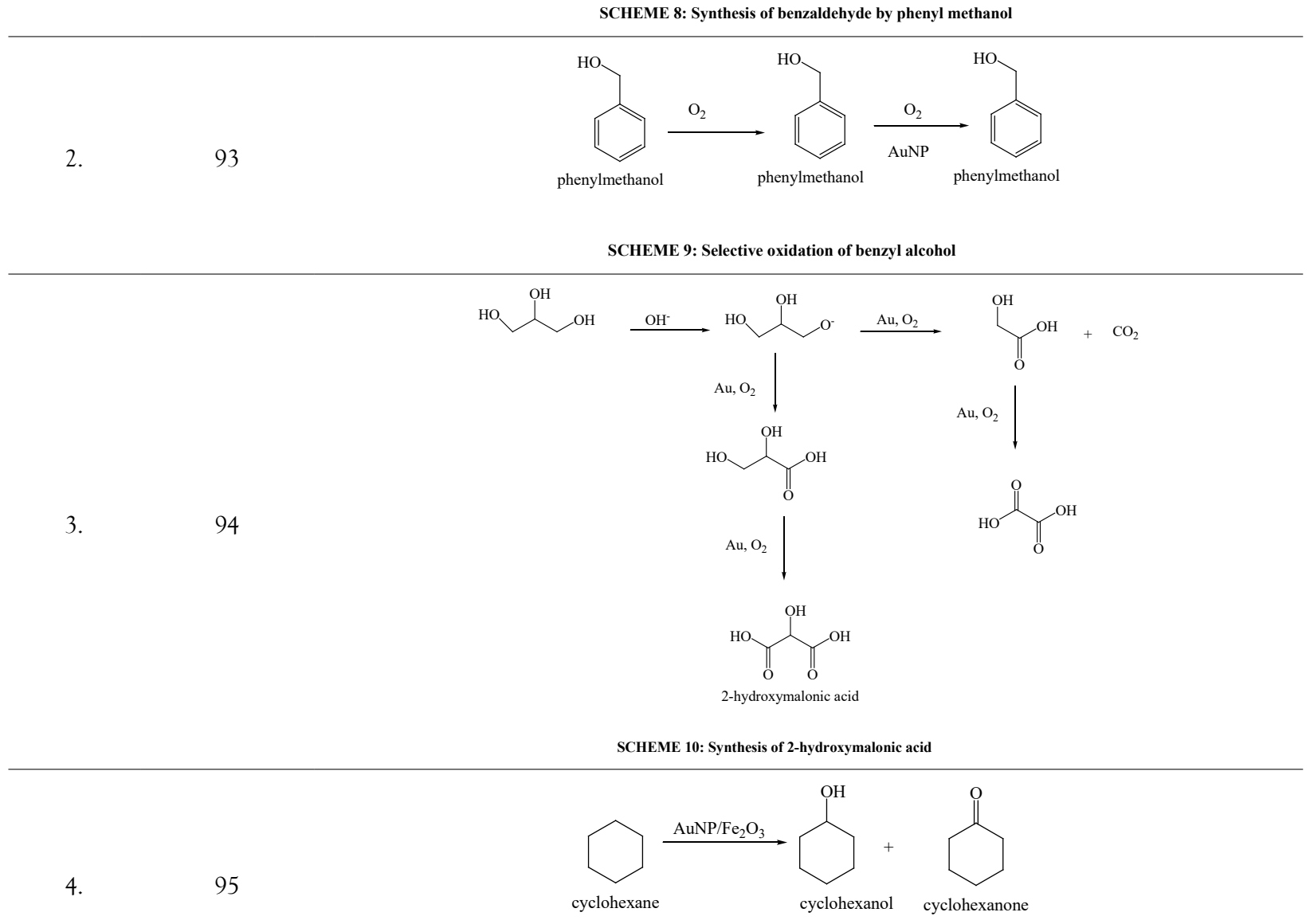

SCHEME 11: Synthesis of cyclohexanol and cyclohexanone from cyclohexane

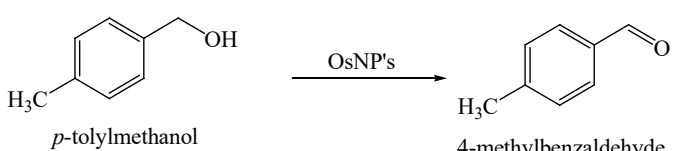

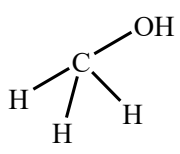

methanol

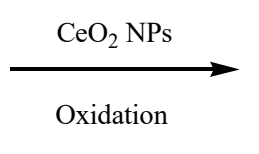

formaldehyde
$\mathrm{H}_{2}$

$\mathrm{CeO}_{2}$

\section{SCHEME 13: Synthesis of Formaldehyde by methanol}

highly substituted pyridines as privileged medicinal scaffolds.[24] Calcium oxide nanoparticles, as an efficient, non-explosive, ecofriendly, non-volatile, recyclable and easy to handle catalyst, can be used in the catalysis of many organic transformations.

\section{Preparation of $\mathrm{CaO}$ nanoparticles}

$\mathrm{NaOH}(1 \mathrm{~g})$ was added to a mixture of ethylene glycol $(12 \mathrm{ml})$ and $\mathrm{Ca}\left(\mathrm{NO}_{3}\right)_{2} \cdot 4 \mathrm{H}_{2} \mathrm{O}(6 \mathrm{~g})$ and the solution stirred vigorously at room temperature for $10 \mathrm{~min}$; the gel solution was kept about $5 \mathrm{~h}$ at 
Table 3: Conversion of organosilanes to silanols.

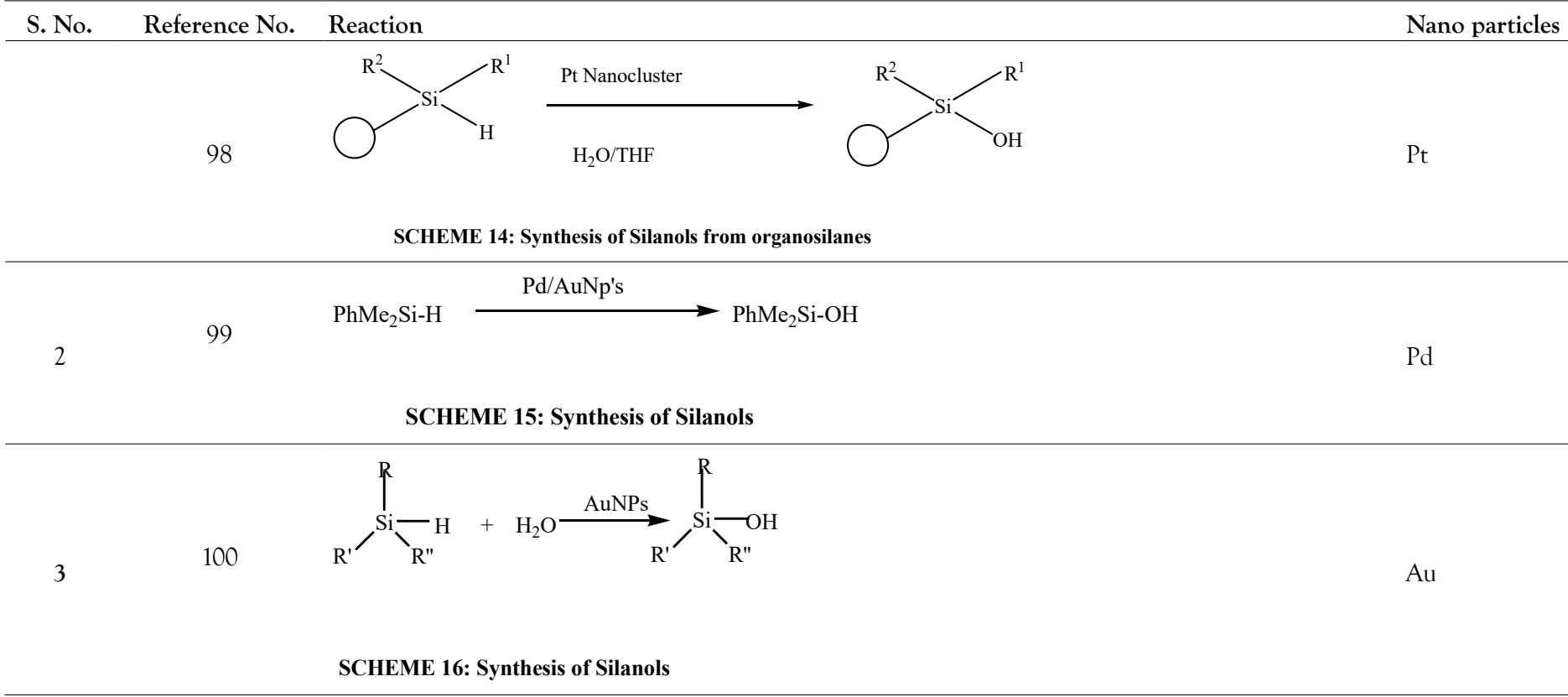

Table 4: Suzuki cross-coupling Reactions and Sonagashira Reaction.

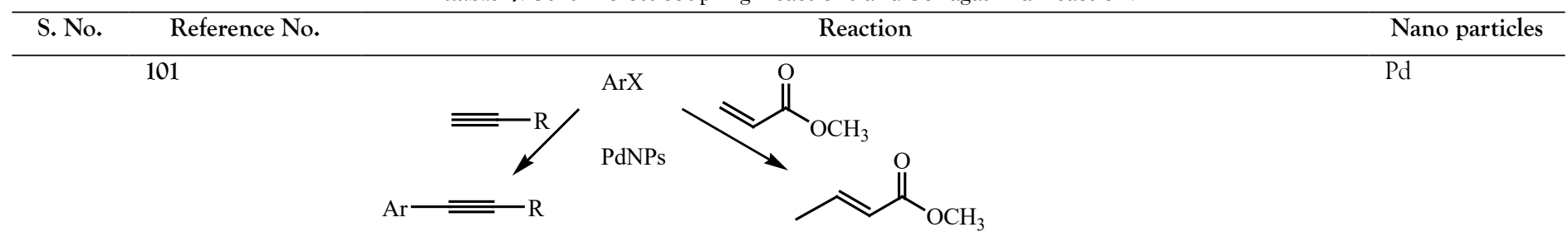

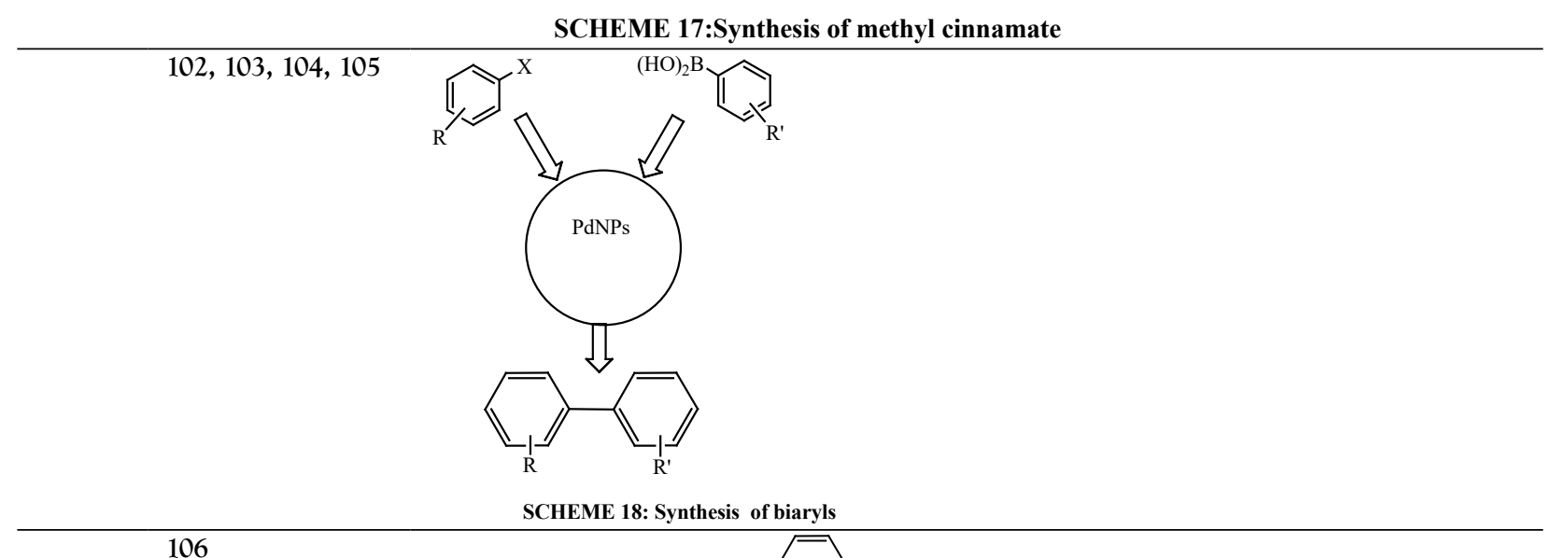

106

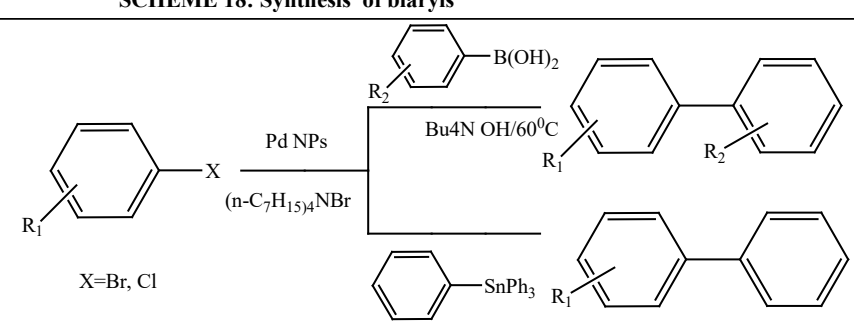

SCHEME 19: Synthesis of substituted biaryls
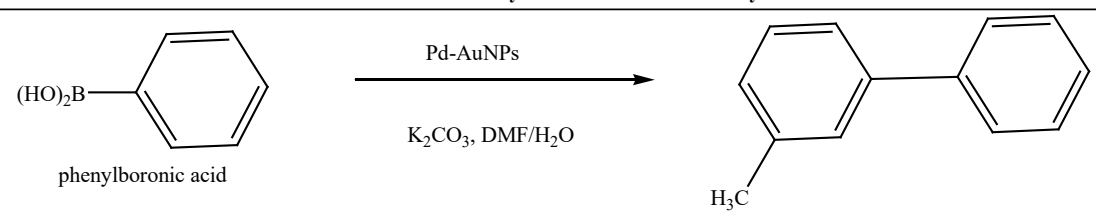

Au-Pd alloy 
Table 5: Hydrogenations.

S. No. Reference No. Reaction $\quad$ Nano particles

1. 109,110

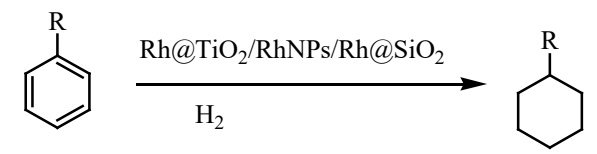

$\mathrm{R}=\mathrm{H}, \mathrm{CH}_{3}, \mathrm{OCH}_{3}$

SCHEME 22: Synthesis of substituted cyclohexanes

2. 111

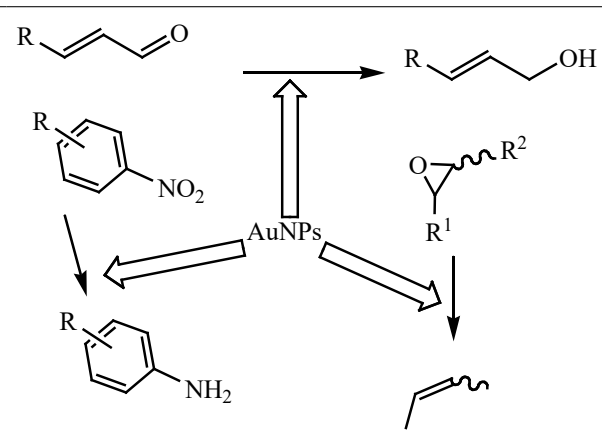

3. 112

4. 113

$$
\mathrm{R}=\mathrm{H} \stackrel{\mathrm{H}_{2}}{\longrightarrow} \underset{\mathrm{H}}{\mathrm{H}}=\mathrm{H}_{\mathrm{H}}^{\mathrm{R}}
$$

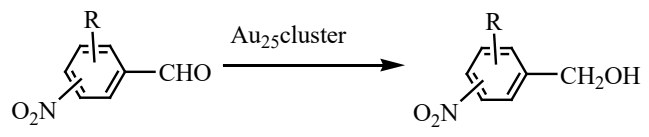

Au nano cluster

SCHEME 24 Synthesis of substituted alkenes<smiles>CC(=O)c1ccccc1</smiles><smiles>Nc1ccccc1</smiles><smiles>CC(O)c1ccccc1</smiles>

Pd

aniline 1-phenylethanol

SCHEME 25:Synthesis of Aniline and 1-phenylethanol

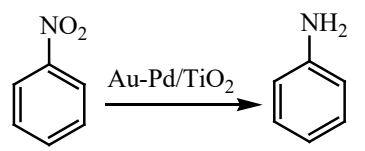

Au-Pd

SCHEME 26: Synthesis of Aniline

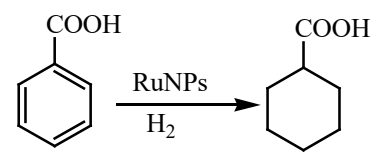

benzoic acid

cyclohexanecarboxylic acid 


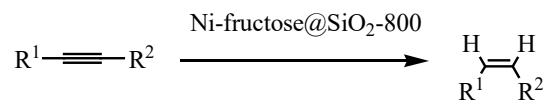

SCHEME 28: Synthesis of Alkene derivatives

1-Hexene $\stackrel{\mathrm{Pd}-\mathrm{Ru} \text { NPs }}{\longrightarrow}$ n-Hexane + cis-2-Hexene + trans-2-Hexene

SCHEME 29:Synthesis of hexanes

118<smiles>Nc1ccc(O)c(C#CC(F)(F)F)c1</smiles>

4-nitrophenol

$$
\text { 4-aminophenol }
$$

Table 6: Ullmann Reaction.

S. No. Reference No.

Table 7: Heck cross-coupling Reaction.

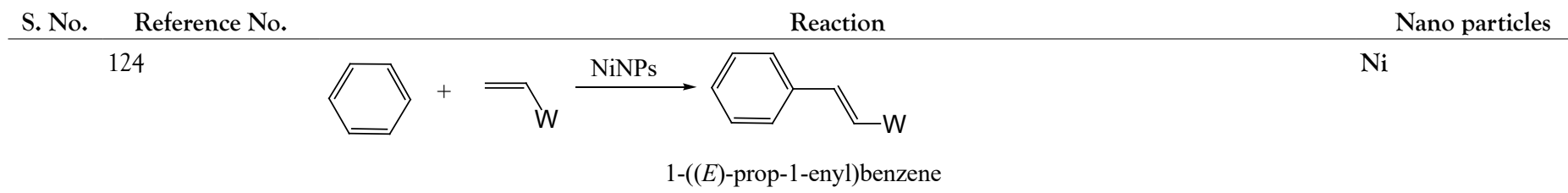

SCHEME 33: Synthesis of 1-((E)-prop-1-enyl)benzene

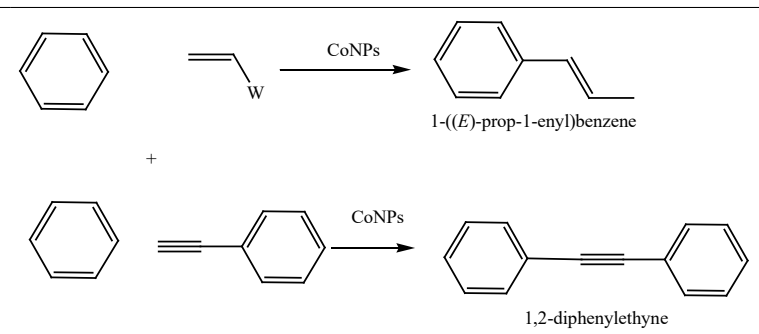


- 126

$$
\mathrm{Ar}-\mathrm{X}+\mathrm{CO}_{2} \mathrm{Bu} \stackrel{\mathrm{PdNPs}}{\longrightarrow}
$$

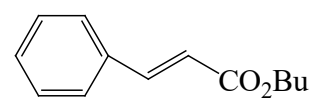

(E)-butyl cinnamate

\section{SCHEME 35 : Synthesis of butyl cinnamate}

127

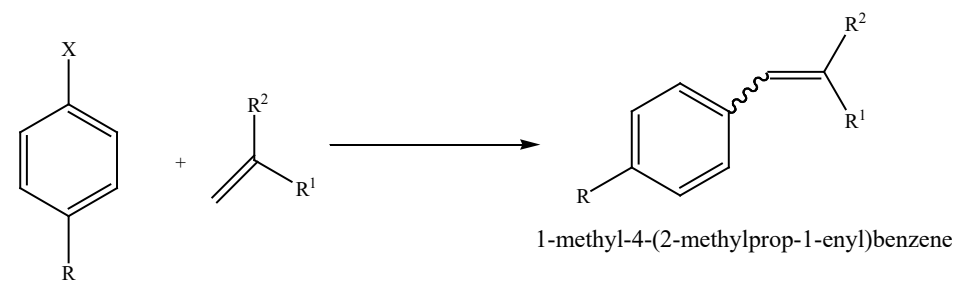

SCHEME 36: 1-methyl-4-(2-methylprop-1-enyl)benzene

128,129
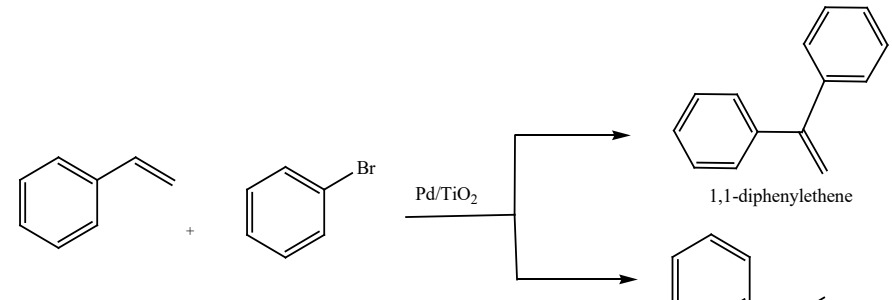

1,1-diphenylethene<smiles>C(=Cc1ccccc1)c1ccccc1</smiles>

1,2-diphenylethene

SCHEME 37: Synthesis of 1,1-diphenyl etane and 1,2-diphenylethan

130

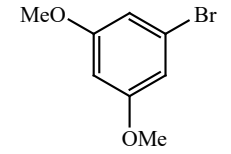

1-bromo-3,5-dimethoxybenzene

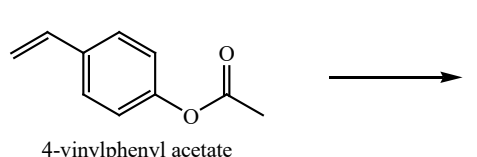

4-vinylphenyl acetate

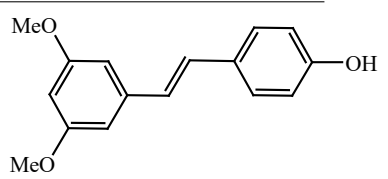

4-(3,5-dimethoxystyryl)phenol

SCHEME 38:Synthesis of 4-(3,5-dimethoxystyryl)pheno

Table 8: Deoxygenation Reaction.

S. No. Reference No.

Reaction

Nanoparticles

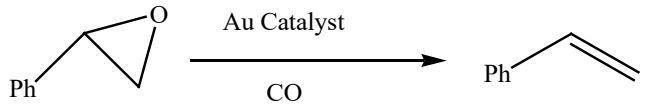

SCHEME 39: Synthesis of Styrene
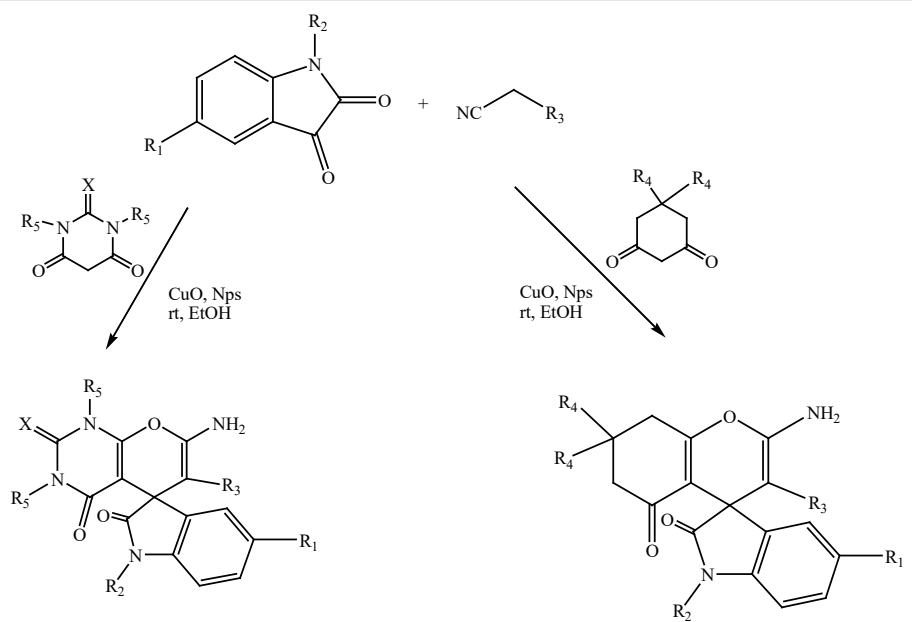

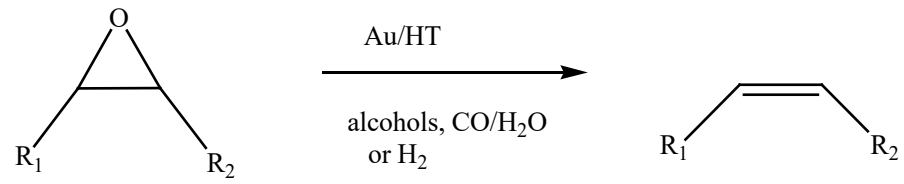

$\mathrm{Au}$

SCHEME 40 : Synthesis of substituted but-2-ene

Table 9: Alkynylation of Aryl Halides.

$\begin{array}{ll}\text { S. No. Reference No. } & \text { Reaction } \\ \text { Scheme 41: Synthesis of } N, N \text {-dialkyl-3-p-tolylprop-2-yn-1-amine } & \text { Narticles } \\ 1 & \end{array}$

Table 10: Arylations and Diarylations.

\section{S. No.}

Reference No.
Reaction Nano particles

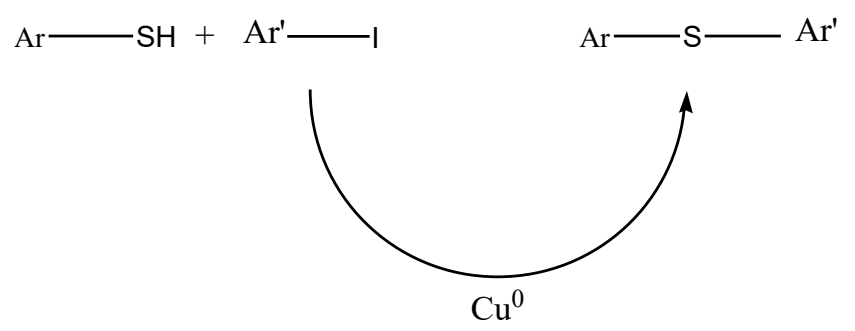

$\mathrm{FeCu}$

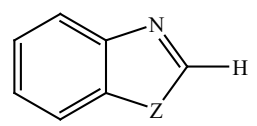

136

137
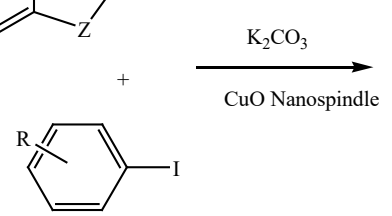

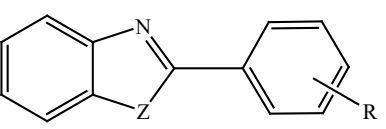

$\mathrm{Z}=\mathrm{O}, \mathrm{S}, \mathrm{NCH}_{3}$

$\mathrm{R}=\mathrm{H}, \mathrm{CN}, \mathrm{Cl}, \mathrm{COOEt}, \mathrm{OCH}_{3}$
$\mathrm{CuO}$

SCHEME 44 : alkyl 3,3-diphenylacrylate

Table 11: Deoxygenation of Epoxides.<smiles>C=CC(=O)O</smiles>

$+2 \mathrm{Ar}$

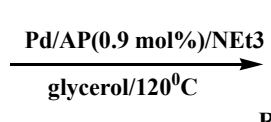

Ro<smiles>O=C(O)C=C([18O])[18O]</smiles>

$\mathrm{Pd}$

S. No. Reference No.

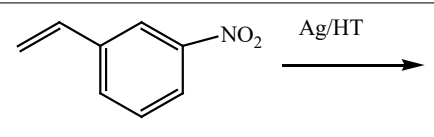

$0.25 \mathrm{mmol}$ Reaction<smiles>C=Cc1cccc([NH3+])c1</smiles>

$>99 \%$ yield<smiles>CCc1cccc(N)c1</smiles>

Not detected
Nanoparticles

138

SCHEME 45: Synthesis of 3-vinylbenzenamine and3-ethylbenzenamine 
Table 12: Oxidative Coupling of Alcohols.

$\begin{array}{llcc}\text { S. No. } \quad \text { Reference No. } & \text { Reaction } & \text { Pano } \\ \text { Particles }\end{array}$

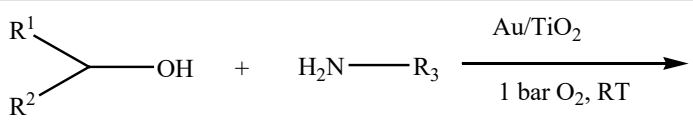<smiles>[R3]N=C([R])[R]</smiles>

$98 \%$ selectivity
$\mathrm{Au}$

SCHEME 46:Synthesis of $N$-(propan-2-ylidene)methanamine

Table 13: Esterification of Alcohols.

S. No. Reference No. Reaction

Nanoparticles<smiles>N#Cc1ccccc1</smiles><smiles>NC(=O)c1ccccc1</smiles>

benzamide

2

141<smiles>[X]c1ccc(C#N)cc1</smiles>

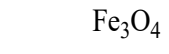<smiles>[X]c1ccc(C(N)=O)cc1</smiles>

Table 14: Hydration of Nitriles.

S. No. Reference No. Reaction 142 Primary alcohols

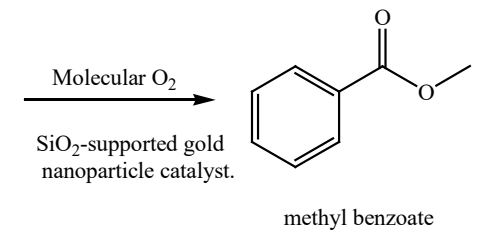

Nano particles<smiles>CCCC(=O)OC</smiles>

methyl butyrate

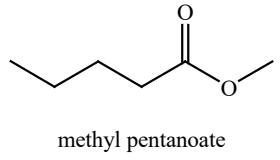

$\mathrm{Au}$

SCHEME 49: Synthesis of methyl esters

Table 15: Additional Organic Synthesis Reactions.

S. No. Reference No.

Reaction

Nano particles
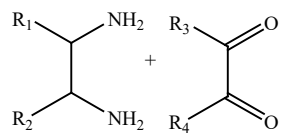

$\underset{\mathrm{H}_{2} \mathrm{O},(\mathrm{r} . \mathrm{t})}{\stackrel{\mathrm{Nano}-\mathrm{Fe}_{3} \mathrm{O}_{4}}{\longrightarrow}}$<smiles>[R9]C1=NC([R3])C([R9])N=C1[2H]</smiles>

$\mathrm{Fe}_{3} \mathrm{O}_{4}$ 


2. 2.

static state. Afterwards, it was washed using water and dried under vacuum drying. Finally, the prepared $\mathrm{CaO}$ nanoparticles were calcinated at $700^{\circ} \mathrm{C}$ for $3 \mathrm{~h} \mathrm{[23].}$

\section{Iron nanoparticles}

Iron nanoparticles have been synthesized using polymers as capping agents in water as green solvent as well as other types of green methods. A green synthesis of iron nanoparticles has been prepared by using tea polyphenols without the use of additional polymers and surfactants [24]. The iron nanoparticles are used to catalyze the hydrogen peroxide for treatment of organic contamination. Iron nanoparticles have been used as environmentally benign catalysts for alkene and alkyne hydrogenations [14]. Iron nanoparticles that have been synthesized used as catalysts for environmentally benign alkene and alkyne hydrogenation reactions [25].

\section{Rhodium nanoparticles}

$\mathrm{CaO}$ and co-workers have reported the catalytic activity of rhodium nanoparticles deposited on modified $\mathrm{SiO}_{2}$ for hydrogenation of nitrile butadiene rubber (NBR) [26]. Kang et al. investigated the morphology control synthesis of Rh nanostructures for cancer treatment [27]. Rhodium nanoparticles were used in Suzuki-Miyamuri reaction and hydrogenation of Benzene by Gniewek and coworkers [28].

$\mathrm{Rh}$ nanoparticles can be synthesized using a variety of green methods such as the hydrogen reduction method in water as solvent, ethanol reduction method in an ethanol water mixture in which the ethanol can be rotovaped, and several other green methods. Rhodium nanoparticles adsorbed onto titanium dioxide supports are synthesized using water as the solvent [29].

\section{Zinc oxide nanoparticles}

Zinc oxide nanoparticles ( $\mathrm{nnO}$ NPs) are cost effective and relatively less toxicity, significant biocompatibility reveal their remarkable biomedical applications, such as anticancer, drug delivery, antibacterial, diabetes treatment and anti-inflammation [30-35].

Due to the strong UV absorption properties of Zinc Oxide, they are used in cosmetics and sunscreen [36-38]. In addition, these particles also show excellent luminescent properties and used for bioimaging $[39,40]$.

Zinc is the most important component of various enzyme systems, it takes part in body's metabolism and plays essential roles in proteins and nucleic acid synthesis, hematopoiesis, and neurogenesis $[41,42]$.

Johnson et al. developed a new method for the green synthesis of $\mathrm{ZnO}$ nanoparticles. In this method, a new leucine-based diamine amphiphile was synthesized and self-assembled. In the presence of $\mathrm{Zn}^{2+}$ ions, the leucine-based diamine amphiphile assembled into nanofibers that efficiently formed $\mathrm{ZnO}$ nanoparticles on heating with $\mathrm{Zn}\left(\mathrm{CH}_{3} \mathrm{COO}\right)_{2}$ [43].

\section{Platinum nanoparticles}

Platinum nanoparticles ( $\mathrm{PtNs}$ ) possess a wide range of properties that can be used for various applications such as catalysts in organic catalysis, fuel cells, hydrogen storage, electrical conductivity, optics and nonlinear optics, coating, plastics, textile, biosensors and biomedicine [44-50]. Engelbrekt and co-workers demonstrated the synthesis of PtNPs using a variety of green methods such as the hydrogen reduction method in water as solvent, ethanol reduction method in an ethanol- water mixture. Monodisperse green $\mathrm{Pt}$ nanoparticles were synthesized by using glucose as the reducing agent and starch as the protective agent [51,52]. This synthesis method is environmentally friendly, highly reproducible, and easy to scale up. These nanocatalysts were tested for reduction and oxidation reactions and were found to have high catalytic activity. Moreover, these $\mathrm{Pt}$ nanoparticles are stabilized with ionic liquids and used as catalysts for four-electron reduction of dioxygen to water [53].

\section{Gold nanoparticles}

In recent years, AuNPs had attracted an immense interests in different fields of science, due to their unique features such as high X-ray absorption coefficient, ease of synthetic strategy, enabling precise control over the particle's physico-chemical properties, strong binding affinity to thiols, disulfides and amines, unique tunable optical and distinct electronic properties [54-60]. The optical-electronics properties of gold nanoparticles are being explored extensively for high technology applications such as sensory probes, electronic conductors, therapeutic agents, organic photovoltaics, Fuel cells, drug delivery in biological and medical applications, and catalysis [61-65].

Itoh et al. investigated the synthesis and functions of gold nanoparticles with ionic liquids based on the imidazolium cation. 
At room temperature green imidazolium-based ionic liquids such as 1-butyl-3-methylimidazolium hexafluorophosphate are used as liquid media for the synthesis of gold nanoparticles which can be used in dyes [66].

The gold nanoparticles were prepared by the addition of $\mathrm{HAuCl}_{4}$ to green tea leaves extract at room temperature. The synthesis of the Au nanoparticles does not involve any toxic chemicals/ organic solvents so it is a green synthetic process. The gold nanoparticles are used as catalysts for the reduction of methylene blue dye [67]. Au nanoparticles have been synthesized by a green photo catalytic method in which the synthesis is conducted in water [68]. Calcium-alginate stabilized gold nanoparticles are prepared using a photochemical green synthetic method [69]. Zhan and coworkers used $\mathrm{Au}$ nanoparticles as catalysts for the 4-nitrophenol reduction reaction. They have prepared Gold/TS-1 nanoparticles using two green routes which are sol-immobilization method and adsorption reduction method [70]. This gold nanoparticle catalyst show excellent performance for the propylene oxidation reaction.

\section{Silver nanoparticles}

Silver nanoparticles have commercialization applications for instance, sterilizing nanomaterials in consuming and medical products, textiles, food storage bags, refrigerator surfaces, and personal care products [71-74]. Additionally, they show optical, thermal, and catalytic properties and antimicrobial ability [75-79].

Silver nanoparticles have been synthesized using several green methods such as the seed-mediated growth method, in the presence of ionic liquids, and other reduction methods such as hydrazine reduction method, and sodium borohydride reduction method. Ag nanoparticles have been synthesized by a green photocatalytic method in which reaction is conducted in water [68]. Calciumalginate stabilized silver nanoparticles are prepared using a photochemical green synthetic method [69]. These nanoparticles are used as catalysts for the 4-nitrophenol reduction reaction.

\section{Aluminium nanoparticles}

Solvent-free methods as well as methods involving the use of water as solvent have been used to synthesize aluminum oxide nanoparticles. Aluminum oxide nanoparticles are synthesized in water as the solvent which makes it a green nanocatalyst [80].

\section{Bimetallic nanoparticles}

Bimetallic nanoparticles (Figure 2) have been prepared by the ethanol reduction method, hydrogen reduction method, and other green methods. These nanoparticles have been used as catalysts in several organic chemistry, including, oxidation of carbon monoxide in aqueous solutions, hydrogenation of alkenes in organic or biphasic solutions and hydrosilylation of olefins in organic solutions [81,82].

\section{Nickel platinum nanoparticles}

Nickel encapsulated by $\mathrm{Pt}(\mathrm{NiPt})$ has been synthesized using a green colloidal method [83]. Pt NPs are very expensive as electrocatalysts so the remedy for this is to diminish the cost by the synthesis of $\mathrm{Ni}$ Pt bimetallic nanoparticles.

\section{Gold-palladium nanoparticles}

Au-Pd nanoparticles are preared in the absence of organic ligands and adsorbed onto $\mathrm{TiO}_{2}$ supports and is found to be stable in oxidative catalysis conditions [84]. It was investigated that $70 \%$ gold, $30 \% \mathrm{Pd}$ composition of the bimetallic nanoparticles show the highest catalytic activity for the oxidative catalysis.

\section{Application of various nanoparticles in green reactions}

Applications of different nanoparticles in green reactions are brief in Figure 3 and summarized in Tables 1-15 [85-145].

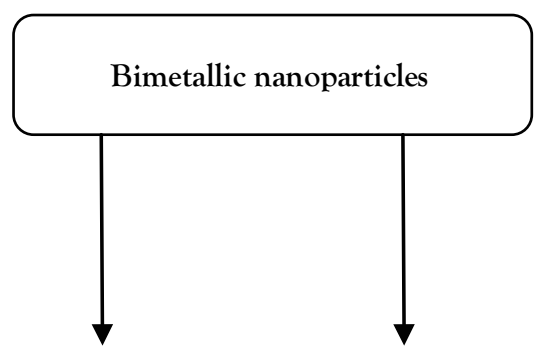

Nickel-Platinum nanoparticles

Gold-Palladium nanoparticles

Ni-Pt NPs

Au-Pd NPs

Figure 2: Bimetallic Nanoparticles.

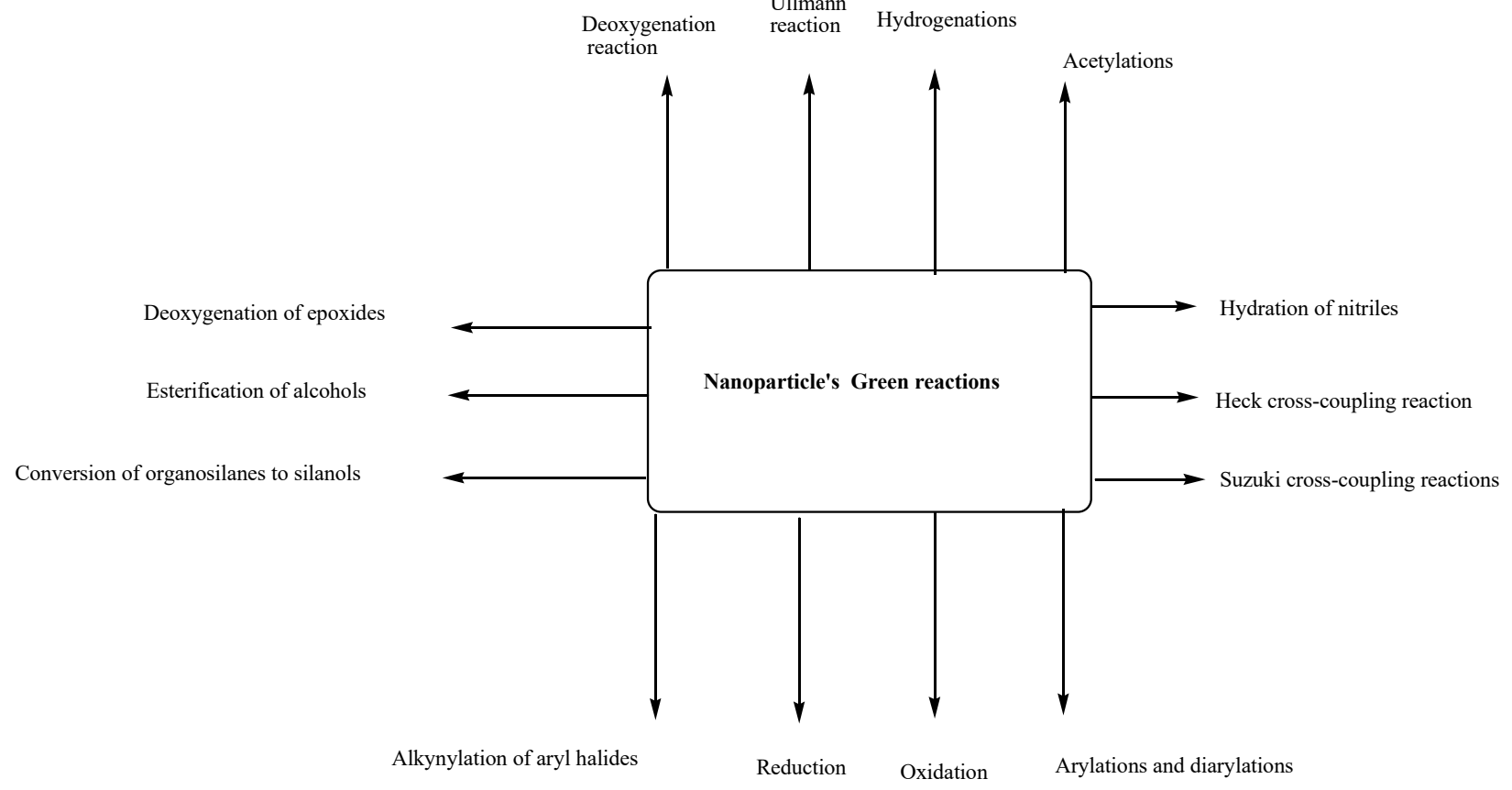

Figure 3: Varoius nanoparticles green reactions. 


\section{CONCLUSION}

There been many different types of metal nanoparticles that have been used as catalysts for many reactions. In many cases, the metal nanoparticles are synthesized in aqueous solution in which water is the solvent, or is conducted in the presence of ionic liquids. There have also been cases where the nanoparticles are used as catalysts for different types of green reactions. Green reaction conditions include using water as the solvent, using solvent that is organicfree, conducting the reaction using ionic liquids, and running the reaction at atmospheric pressure. While there has been a lot of progress in applying the use of green chemistry to catalysis with nanoparticles, there is lot more room to further expand this field. In this review article, we have focused on the synthesis of various nanoparticles and their use in organic synthesis. Still there is need to explore and to synthesize new nanocatalysts with more properties. This review provides a comprehensive understanding on organic reactions which are catalyzed using environmentally friendly nanoparticles and nanocatalysts.

\section{ACKNOWLEDGEMENTS}

We would like to thank to NPIU-TEQIP, AICTE, MHRD for research fund in CRS Project (CRS ID: 1-5724887263).

\section{CONFLICT OF INTEREST}

No authors have stated any conflicts of interest.

\section{CONTRIBUTIONS}

The manuscript was written through contributions of all authors. All authors have given approval to the final version of the manuscript.

\section{REFERENCES}

1. Bing Z, Scott H, Raja R, Somorjai GA. Springer Nanotechnology in Catalysis 2007;3.

2. Min Y, Akbulut M, Kristiansen K, Golan Y, Israelachvili J. The role of interparticle and external forces in nanoparticle assembly. Nat Mater 2008; 7:527-538.

3. Astruc D. Wiley Nanoparticles and Catalysis 2008;1.

4. Zabeti M, Wan Daud WMA, Kheireddine MA. Optimization of the activity of $\mathrm{CaO} / \mathrm{Al}_{2} \mathrm{O}_{3}$ catalyst for biodiesel production using response surface methodology. Appl Catal A Gen 2009;366:154-159.

5. Demirbas A. Biodiesel from sunflower oil in supercritical methanol with calcium oxide. Energy Convers Manage 2007;48:937-941.

6. Granados ML; Poves MDZ, Alonso DM, Mariscal R, Galisteo FC, Moreno-Tost R, Santamaria J, Fierro JLG. Biodiesel from sunflower oil by using activated calcium oxide. Appl Catal B Environ 2007;73:317-326.

7. Oladoja NA, Ololade IA, Olaseni SE, Olatujoye VO, Jegede OS, Agunloye AO. Synthesis of nano calcium oxide from a gastropod shell and the performance evaluation for $\mathrm{Cr}(\mathrm{VI})$ removal from aqua system. Ind Eng Chem 2012;51:639-648.

8. Martínez SL, Romero R, Lopez JC, Romero A, Mendieta VS, Natividad $\mathrm{R}$, et al. Preparation and characterization of $\mathrm{CaO}$ nanoparticles/ $\mathrm{NaX}$ zeolite catalysts for the transesterification of sunflower oil. Ind Eng Chem Res 2011;50:2665-2670.

9. Wan Z, Hameed BH, Transesterification of palm oil to methyl ester on activated carbon supported calcium oxide catalyst. Bioresource Technol 2011;102:2659-2664.

10. do Nascimento GS, Mambrini GP, Paris EC, Peres JA, Colnago LA, Ribeiro C, et al. Evaluation of the catalytic activity of oxide nanoparticles synthesized by the polymeric precursor method on biodiesel production. J Materials Res 2012;27:3020-3026.

11. Dalibor MM, Miroslav VS, Ana VV, Jelena MA, Milord DC, Vlada BV, et al. The synthesis of $\mathrm{CaO}$ loaded onto $\mathrm{Al}_{2} \mathrm{O}_{3}$ from calcium acetate and its applications in the transesterification of the sunflower oil. Adv Technol 2015;4(1):26-32.

12. Sung MS, Katsuki K. Transesterification of sunflower oil in a counter current trickle-bed reactor packed with a $\mathrm{CaO}$ catalyst. Chem Eng Process 2011;50:650-654.

13. Kaur M, Ali A. Lithium ion impregnated calcium oxide as nano catalyst for the biodiesel production from karanja and jatropha oils. Renew Energy 2011;36:2866-2671.

14. Kaur N, Ali A. Kinetics and reusability of $\mathrm{Zr} / \mathrm{CaO}$ as heterogeneous catalyst for the ethanolysis and methanolysis of Jatropha crucas oil. Fuel Process Technol. 2014;119:173-84.

15. Kaur M, Ali, A. Potassium fluoride impregnated $\mathrm{CaO} / \mathrm{NiO}$ : An efficient heterogeneous catalyst for transesterification of waste cottonseed oil. Eur J Lipid Sci Technol 2014;116:80-88.

16. Kumar D, Ali, A. Nanocrystalline $\mathrm{K}-\mathrm{CaO}$ for the transesterification of a variety of feedstocks: structure, kinetics and catalytic properties. Biomass- Bioenergy 2012;46:459-468.

17. Kumar D, Ali, A. Nanocrystalline lithium ion impregnated calcium oxide as heterogeneous catalyst for transesterification of high moisture containing cotton seed oil. Energy Fuel 2010;24:2091-2097.

18. Reddy CRV, Oshel R, Verkade JG. Room-temperature conversion of soybean oil and poultry fat to biodiesel catalyzed by nanocrystalline calcium oxides. Energy Fuel 2006;20:1310-1314.

19. Wen L, Wang Y, Lu D, Hu S, Han H. Preparation of $\mathrm{KF} / \mathrm{CaO}$ nanocatalyst and its application in biodiesel production from Chinese tallow seed oil. Fuel 2010;89:2267-2271.

20. Cai GB, Zhao GX, Wang XK, Yu SH. Direct synthesis of hollow vaterite nanospheres from amorphous calcium carbonate nanoparticles via phase transformation. J Phys Chem C 2010;114:12948-12954.

21. Najafpour MM, Nayeri S, Pashaei B. Nano-size amorphous calciummanganese oxide as an efficient and biomimetic water oxidizing catalyst for artificial photosynthesis: back to manganese. Dalton Trans 2011; 40:9374-9378.

22. Osuntokun J, Onwudiwe DC, Ebenso EE. Aqueous extract of broccoli mediated synthesis of $\mathrm{CaO}$ nanoparticles and its application in the photocatalytic degradation of bromocrescol green. IET Nanobiotechnology 2018;12(7):888-894.

23. Safaei-Ghomi J, Ghasemzadeha MA, Mehrabib M. Calcium oxide nanoparticles catalyzed one-step multicomponent synthesis of highly substituted pyridines in aqueous ethanol media. Scientia Iranica C 2013;20(3):549-554

24. Hoag GE, Collins JB, Holcomb JL, Hoag JR, Nadagouda MN, Varma RS. J Mater Chem. 2009;19(45): 8671-8677.

25. Phua P -H, Lefort L, Boogers JAF, Tristany M, de Vries JG. Chem Commun 2009;25:3747-3749.

26. Cao P, Ni Y, Zou R, Zhang L, Yue D. Enhanced catalytic properties of rhodium nanoparticles deposited on chemically modified $\mathrm{SiO}_{2}$ for hydrogenation of nitrile butadiene rubber. RSC Adv 2015;5:3417-3424.

27. Kang S, Shin W, Choi Myung-Ho, Ahn M, Kim Y-K, Kim S, Min D.-H, Jang H. Morphology-Controlled Synthesis of Rhodium Nanoparticles for Cancer Phototherapy. ACS Nano 2018;12(7):6997-7008.

28. Gniewek A, Trzeciak A M. Rh(0) Nanoparticles: Synthesis, Structure and Catalytic Application in Suzuki-Miyaura Reaction and Hydrogenation of Benzene. Topics in Catalysis 2013;56(12):1239-1245.

29. Hubert C, Denicourt-Nowicki A, Beaunier P, Roucoux A. TiO ${ }_{2}$-supported 
Rh nanoparticles: From green catalyst preparation to application in arene hydrogenation in neat water. Green Chem 2010;12(7):1167- 1170.

30. Mishra PK, Mishra H, Ekielski A, Talegaonkar S, Vaidya B. Zinc oxide nanoparticles: a promising nanomaterial for biomedical applications. Drug Discovery Today 2017;22(12):1825-1834.

31. Kim S, Lee Y, Cho HJ. Doxorubicin-wrapped zinc oxide nanoclusters for the therapy of colorectal adenocarcinoma. Nanomaterials 2017;7(11):354.

32. Jiang J, Pi J, Cai J. The Advancing of Zinc Oxide Nanoparticles for Biomedical Applications. Bioinorg Chem Appl Article ID 1062562 2018;1-18.

33. Zhang Y, Nayak TR, Hong H, Cai W. Biomedical applications of zinc oxide nanomaterials. Current Mol Med 2013;13(10):1633-1645.

34. Martinez-Carmona M, Gun'ko Y, Vallet-Regi M. ZnO nanostructures for drug delivery and theranostic applications. Nanomaterials 2018;8(4):268.

35. Sharma V, Anderson D, Dhawan A. Zinc oxide nanoparticles induce oxidative DNA damage and RO Striggered mitochondria mediated apoptosis in human liver cells (HepG2). Apoptosis 2012;17(8):852-870.

36. Newman MD, Stotland M, Ellis JI. The safety of nanosized particles in titanium dioxide- and zinc oxide based sunscreens. J Am Acad Dermat 2009;61(4):685-692.

37. Smijs TG, Pavel S. Titanium dioxide and zinc oxide nanoparticles in sunscreens: focus on their safety and effectiveness. Nanotechnology Sci Appl 2011;4:95-112.

38. Ruszkiewicz JA, Pinkas A, Ferrer B, Peres TV, Tsatsakis A, Aschner M. Neurotoxic effect of active ingredients in sunscreen products, a contemporary review. Toxicology Reports 2017;4:245-259.

39. Xiong $\mathrm{H} \mathrm{M}$. $\mathrm{ZnO}$ nanoparticles applied bioimaging and drug delivery. Advanced Materials 2013;25(37): 5329-5335.

40. Zhang ZY, Xiong HM. Photoluminescent ZnO nanoparticles and their biological applications. Materials 2015;8(6):3101-3127.

41. Kolodziejczak-Radzimska A, Jesionowski T. Zinc oxide-from synthesis to application: a review. Materials 2014;7(4):2833-2881.

42. Sahoo S, Maiti M, Ganguly A, George JJ, Bhowmick AK. Effect of zinc oxide nanoparticles as cure activator on the properties of natural rubber and nitrile rubber. J App Polymer Sci 2007;105(4):2407-2415.

43. Johnson KT, Gribb TE, Smoak EM, Banerjee IA. Self-assembled nanofibres from leucine derived amphiphiles as nanoreactors for growth of ZnO nanoparticles. Chem Commun 2010;46:1757-1759.

44. Reddington E, Sapienza A, Gurau B, Viswanathan R, Sarangapani S, Smotkin ES, et al. Combinatorial Electrochemistry: A Highly Parallel, Optical Screening Method for Discovery of Better Electrocatalysts. Science 1998;280:1735-1737.

45. Williams KR, Burstein GT. Low temperature fuel cells: Interactions between catalysts and engineering design. Catalysis Today 1997;38(4):401-410.

46. Bell AT. The impact of nanoscience on heterogeneous catalysis. Science 2003;299:1688-1691.

47. Sun S, Murray CB, Weller D, Folks L, Moser A. Monodisperse FePt nanoparticles and ferromagnetic Fe- Pt nanocrystal superlattices. Science 2000;287:1989-1992.

48. Chen Chun-Wei, Akashi M. Synthesis, Characterization, and Catalytic Properties of Colloidal Platinum Nanoparticles Protected by Poly(Nisopropylacrylamide). Langmuir 1997;13(24):6465-6472.

49. Huang KX, Mai Z, Zou X, Cai P, Mo J. Glucose biosensors based on platinum nanoparticles-deposited carbon nanotubes in sol-gel chitosan/silica hybrid. Talanta 2008;74:879-886.
50. Pedone D, Moglianetti M, Luca ED, Bardi G, Pompa PP. Platinum nanoparticles in nanobiomedicine. Chem Soc Rev 2017;46:4951-4975.

51. Narayanan, R. Synthesis of green nanocatalysts and industrially important green reactions. Green Chem Lett Rev 2014;5(4):707-725.

52. Engelbrekt C, Soerensen KH, Luebcke T, ZhangJ, Li Q, Pan C, et al. $1.7 \mathrm{~nm}$ Platinum Nanoparticles: Synthesis with Glucose Starch, Characterization and Catalysis. J Chem Phys Chem 2010; 11(13):2844-2853.

53. Li F, Song J, Song J, Han D, Niu L. Green synthesis of highly stable platinum nanoparticles stabilized by amino-terminated ionic liquid and its electrocatalysts for dioxygen reduction and methanol oxidation. Electrochem Commun 2009;11(2):351-354.

54. Zhou Y, Wang CY, Zhu YR, Chen ZY. A novel ultraviolet irradiation technique for shape-controlled synthesis of gold nanoparticles at room temperature. Chem Mater 1999,11:2310-2312.

55. Zhao P, Li N, Astruc D. State of the art in gold nanoparticle synthesis. Coord Chem Rev 2013;257: 638-665.

56. Zhang Z, Chen Z, Cheng F, Zhang Y, Chen L. Highly sensitive onsite detection of glucose in human urine with naked eye based on enzymatic-like reaction mediated etching of gold nanorods. Biosens. Bioelectron. 2017;89:932-936.

57. Zhang Z, Wang J, Nie X, Wen T, Ji Y, Wu X, et al. Near infrared laserinduced targeted cancer therapy using thermoresponsive polymer encapsulated gold nanorods. J Am Chem Soc 2014;136: 7317-7326.

58. Zhang Y, Chu W, Foroushani AD, Wang H, Li D, Liu J, et al. New gold nanostructures for sensor applications: a review. Materials 2014;7:5169-5201.

59. Zhang Y, Qian J, Wang D, Wang Y, He S. Multifunctional gold nanorods with ultrahigh stability and tunability for in vivo fluorescence imaging, SERS detection, and photodynamic therapy. Angew Chem Int Ed 2013;52:1148-1151.

60. Zhang X. Gold nanoparticles: recent advances in the biomedical applications. Cell Biochem Biophys. 2015;72:771-775.

61. Saha K, Agasti SS, Kim C, Li X, Rotello VM. Gold Nanoparticles in Chemical and Biological Sensing. Chem Rev 2012;112(5):2739-2779.

62. Kamali M, Baghersad H. Recent biomedical applications of gold nanoparticles: A review. Talanta 2018; 184:537-556.

63. Schmid G, Simon U. Gold nanoparticles: assembly and electrical properties in 1-3 dimensions. Chem Commun 2005;697-710.

64. Saxena U, Goswami P. Electrical and optical properties of gold nanoparticles: applications in gold nanoparticles-cholesterol oxidase integrated systems for cholesterol sensing. J Nanopart Res 2012;14: 813.

65. Chuan-Jian Z, Luo J, Mott D, Maye MM, Kariuki N, Wang L, et al. Gold-Based Nanoparticle Catalysts for Fuel Cell Reactions. Nanotechnology in Catalysis 2007;289-307.

66. Itoh H, Naka K, Chujo Y. Synthesis of Gold Nanoparticles Modified with Ionic Liquid Based on the Imidazolium Cation. J Am Chem Soc 2004;126:3026-3027.

67. Gupta N, Singh HP, Sharma RK. Metal nanoparticles with high catalytic activity in degradation of methyl orange: An electron relay effect. J Mol Cat A: Chemical 2011;335:248-252.

68. Quaresma P, Soares L, Contar L, Miranda A, Osorio I, Carvalho PA, et al. Green photocatalytic synthesis of stable $\mathrm{Au}$ and $\mathrm{Ag}$ nanoparticles. Green Chem 2009;11:1889-1893.

69. Saha S, Pal A, Kundu S, Basu S, Pal T. Photochemical Green Synthesis of Calcium-Alginate-Stabilized Ag and Au Nanoparticles and Their Catalytic Application to 4-Nitrophenol Reduction. Langmuir 2009;26(4):2885-2893.

70. Zhan G, Du M, Huang J, Li Q. Green synthesis of Au/TS-1 catalysts 
via two novel modes and their surprising performance for propylene epoxidation. Catal Commun 2011;12(9):830-833.

71. Bapat RA, Chaubal TV, Joshi CP, Bapat PR, Choudhury H, Pandey $\mathrm{M}$, et al. An overview of application of silver nanoparticles for biomaterials in dentistry. Mat Sci Eng C 2018;91:881-898.

72. Prabhu S, Poulose EK. Silver nanoparticles: mechanism of antimicrobial action, synthesis, medical applications, and toxicity effects. Inter Nano Letters 2012;2:32.

73. Kholoud MM, Abou El-Noura, Eftaiha A, Al-Warthan A, Ammar RAA. Synthesis and applications of silver nanoparticles. Arab J Chem 2010;3:135-140.

74. Tran QH, Nguyen VQ, Le A-T. Silver nanoparticles: synthesis, properties, toxicology, applications and perspectives. Adv Nat Sci Nanosci Nanotech 2013:4(3):033001.

75. Monteiro DR, Gorup LF, Takamiya AS, Ruvollo-Filho AC, deCamargo ER, Barbosa DB. The growing importance of materials that prevent microbial adhesion: antimicrobial effect of medical devices containing silver. Antimicrob Agents 2009;34:103-110.

76. Ahamed M, Alsalhi MS, Siddiqui MK. Silver nanoparticle applications and human health. Clin Chim Acta 2010;411:1841-1848.

77. Garc'1a-Barrasa J, Lopez-de-luzuriaga JM, Monge M. Silver nanoparticles: synthesis through chemical methods in solution and biomedical applications. Cent Eur J Chem 2011;9:1-17.

78. Fabrega J, Luoma SN, Tyler CR, Galloway TS, Lead JR. Silver nanoparticles: behaviour and effects in the aquatic environment. Environ Inter 2011;37:517-531.

79. Dallas P, Sharma VK, Zbori, R. Silver polymeric nanocomposites as advanced antimicrobial agents: classification, synthetic paths, applications, and perspectives. Adv. Colloid Interface Sci. 2011, 166, $119-135$.

80. Kassaee MZ, Rostamizadeh S, Shadjou N, Motamedi E, Esmaeelzadeh M. An efficient one-pot solvent-free synthesis of 2,3-dihydroquinazoline$4(1 \mathrm{H})$-ones via $\mathrm{Al} / \mathrm{Al}_{2} \mathrm{O}_{3}$ nanoparticles. J Heterocycl Chem 2010;47(6):1421-1424.

81. Chen Chun-Wei, Akashi M. Synthesis, Characterization, and Catalytic Properties of Colloidal Platinum Nanoparticles Protected by Poly(Nisopropylacrylamide). Langmuir 1997;13(24):6465-6472.

82. Shiraishi Y, Sakamoto H, Sugano Y, Ichikawa S, Hirai T. Pt-Cu Bimetallic Alloy Nanoparticles Supported on Anatase $\mathrm{TiO}_{2}$ :Highly Active Catalysts for Aerobic Oxidation Driven by Visible Light. ACS Nano 2013;7(10):9287-9297.

83. Medina-Ramirez I, Pan X, Bashir S, Liu J. In Green Synthesis of Platinum-Encapsulated Nickel Nanocatalyst and its Nanostructure evaluation. Materials Research Society Symposium Proceedings 1213E 2009;1213-T10-12.

84. Frank AJ, Rawski J, Maly KE, Kitaev V. Environmentally benign aqueous oxidative catalysis using $\mathrm{Au}-\mathrm{Pd} / \mathrm{TiO}$, colloidal nanoparticle system stabilized in absence of organic ligands. Green Chem 2010;12(9): 1615-1622.

85. Iordanidou D, Zarganes-Tzitzikas T, Neochoritis CG, Do囚mling A, Lykakis IN. Application of Silver Nanoparticles in the Multicomponent Reaction Domain: A Combined Catalytic Reduction Methodology to Efficiently Access Potential Hypertension or Inflammation Inhibitors. ACS Omega 2018;3:16005-16013.

86. Saha J, Begum A, Mukherjee A, Kumar S. A novel green synthesis of silver nanoparticles and their catalytic action in reduction of Methylene Blue dye. Sustan Env Res 2017;27:245-250.

87. Ostojic N, Duan Z, Galyamova A, Henkelman G, Crooks RM. Electrocatalytic Study of the Oxygen Reduction Reaction at Gold
Nanoparticles in the Absence and Presence of Interactions with $\mathrm{SnOx}$ Supports. J Am Chem Soc 2018;140(42):13775-13785.

88. Ke X, Sarina S, Zhao J, Zhang X, Chang J, Zhu H, et al. Tuning the reduction power of supported gold nanoparticle photocatalysts for selective reductions by manipulating the wavelength of visible light irradiation. Chem Commun 2012;48:3509-3511.

89. Ke X, Zhang X, Zhao J, Sarina S, Barry J, Zhu H, et al. Selective reductions using visible light photocatalysts of supported gold nanoparticles. Green Chem 2013;15:236-244.

90. Zhu H, Ke X, Yang X, Sarina S, Liu H. Reduction of Nitroaromatic Compounds on Supported Gold Nanoparticles by Visible and Ultraviolet Light. Angew Chem Int Ed 2010;49:9657-9661.

91. Devivaraprasad R, Nalajala N, Bera B, Neergat M Pt-Cu Bimetallic Alloy Nanoparticles Supported on Anatase $\mathrm{TiO}_{2}$ : Highly Active Catalysts for Aerobic Oxidation Driven by Visible Light. ACS Nano 2013; 7(10):9287-9297.

92. Choudhary VR, Dhar A, Jana P, Jha R, Uphade BS. A green process for chlorine-free benzaldehyde from the solvent-free oxidation of benzyl alcohol with molecular oxygen over a supported nano-size gold catalyst. Green Chem 2005;7(11):768-770

93. Pereira LNS, Ribeiro CES, Tofanello A, Costa JCS, de Moura CVR, Garcia MAS, et al. Gold Supported on Strontium Surface-Enriched $\mathrm{CoFe}_{2} \mathrm{O}_{4}$ Nanoparticles: A Strategy for the Selective Oxidation of Benzyl Alcohol. J Braz Chem Soc 2019;30(6):1317-1325.

94. Ide MS, Davis RJ. The Important Role of Hydroxyl on Oxidation Catalysis by Gold Nanoparticles. Acc Chem Res 2014;47(3):825-833.

95. Martins LMDRS, Carabineiro SAC, Wang J, Rocha BGM, MaldonadoHódar FJ, Pombeiro, AJ L, et al. Supported Gold Nanoparticles as Reusable Catalysts for Oxidation Reactions of Industrial Significance. Chem Cat Chem Catalysis 2017;9(7):1211-1221.

96. Santacruz L, Donnici S, Shafir A, Vallriber A. Fluoro-tagged osmium and iridium nanoparticles in oxidation reactions. Tetrahedron 2018;74:6890-6895.

97. Bayahia H. Cerium Oxide Nanoparticles Catalyst for the Oxidation of Methanol. Orient J Chem 2019; 35(5):1539-1545.

98. Chauhan BPS, Sarkar A, Chauhan M, Roka A. Water as green oxidant: a highly selective conversion of organosilanes to silanols with water. Appl Organomet Chem 2009;23(10):385-390.

99. Jeon M, Han J, Park J. Transformation of Silanes into Silanols using Water and Recyclable Metal Nanoparticle Catalysts. Chem Cat 2012;4:521-524.

100. Gitis V, Beerthuis R, Shiju NR, Rothenberg G. Organosilane oxidation by water catalysed by large gold nanoparticles in a membrane reactor. Catal Sci Technol 2014;4:2156-2160.

101. Bernini R, Cacchi S, Fabrizi G, Forte G, Petrucci F, Prastaro A, et al. Perfluoro-tagged, phosphine-free palladium nanoparticles supported on silica gel: application to alkynylation of aryl halides, Suzuki-Miyaura crosscoupling, and Heck reactions under aerobic condition. Green Chem 2010; 12(1):150-158.

102. Pérez-Lorenzo M. Palladium Nanoparticles as Efficient Catalysts for Suzuki Cross-Coupling Reactions. J Phys Chem Lett 2012;3:167-174.

103. Mandali PK, Chand DK. Palladium nanoparticles catalyzed Suzuki cross-coupling reactions in ambient conditions. Cat Commun 2013;13:16-20.

104. Panchal M, Kongor A, Mehta V, Vora M, Bhat K, Jain V, et al. Hecktype olefination and Suzuki couplingreactions using highly efficient oxacalix[4]arenewrapped nanopalladium catalyst. J Saudi Chem Soc 2018;22:558-568.

105. Gaikwad DS, Undale KA, Patil DB, Pore DM. Multi-functionalized 
ionic liquid with in situ-generated palladium nanoparticles for Suzuki, Heck coupling reaction: a comparison with deep eutectic solvents. J Iran Chem Soc 2019;16:253-261.

106. Calò V, Nacci A, Monopoli A, Montingelli F. Pd Nanoparticles as Efficient Catalysts for Suzuki and Stille Coupling Reactions of Aryl Halides in Ionic Liquids. J Org Chem 2005;70(15):6040-6044.

107. Li P, Wang L, Li H. Application of recoverable nanosized palladium (0) catalyst in Sonogashira reaction. Tetrahedron 2005;61(36):86338640 .

108. Xiao Q, Sarina S, Jaatinen E, Jia J, Arnold DP, Liu H, et al. Efficient photocatalytic Suzuki cross-coupling reactions on Au-Pd alloy nanoparticles under visible light irradiation. Green Chem 2014;16:4272-4285.

109. Hubert C, Denicourt-Nowicki A, Beaunier P, Roucoux A. $\mathrm{TiO}_{2}$ supported Rh nanoparticles: From green catalyst preparation to application in arenehydrogenation in neat water. Green Chem 2010;12(7):1167-1170.

110. Hubert C, Bile EG, Denicourt-Nowicki A, Roucoux A. Rh(0) colloids supported on $\mathrm{TiO}_{2}$ : a highly active and pertinent tandem in neat water for the hydrogenation of aromatics. Green Chem 2011;13:1766-1771.

111. Mitsudome T, Kiyotomi K. Gold nanoparticle catalysts for selective hydrogenations. Green Chem 2013;15: 2636-2654.

112. Zhao J, Ge L, Yuan H, Liu Y, Gui Y, Zhang B, et al. Heterogeneous gold catalysts for selective hydrogenation from nanoparticles to atomically precise nanoclusters. Nanoscale 2019;11:11429-11436.

113. Guo M, Li H, Ren Y, Ren X, Yang Q, Li C. Improving Catalytic Hydrogenation Performance of Pd Nanoparticles by Electronic Modulation Using Phosphine Ligands. ACS Catal 2018;8(7):6476-6485.

114. Qu R, Macino M, Iqbal S, Gao X, He Q, Hutchings GJ, et al. Supported Bimetallic AuPd Nanoparticles as a Catalyst for the Selective Hydrogenation of Nitroarenes. Nanomaterials 2018;8(9): 6901-11.

115. Ren X, Guo M, Li H, Li C, Yu L, Liu J, et al. Microenvironment Engineering of Ruthenium Nanoparticles Incorporated into Silica Nanoreactors for Enhanced Hydrogenations. Angew Chem Int Ed 2019;41:14483-14488.

116. Murugesan K, Alshammari AS, Sohail M, Matthias BM, Jagadeesh RV. Monodisperse nickel-nanoparticles for stereo- and chemoselective hydrogenation of alkynes to alkenes. J Catalysis 2019;370: 372-377.

117. Johnson BFG, Raynor SA, Brown DB, Shephard DS, Mashmeyer T, Thomas JM, et al. New catalysts for clean technology. J Mol Catal A Chem 2002;182- 183:89-97.

118. Mori K, Yoshioka N, Kondo Y, Takeuchi T, Yamashita H. Catalytically active, magnetically separable, and water-soluble FePt nanoparticles modified with cyclodextrin for aqueous hydrogenation reactions. Green Chem 2009;11(9):1337-1342.

119. Cheng J, Tang L, Xu J. An Economical, Green Pathway to Biaryls: Palladium Nanoparticles Catalyzed Ullmann Reaction in Ionic Liquid/ Supercritical Carbon Dioxide System. Adv Synth Catal 2010;352 (18):3275-3286.

120. Cheng J, Zhang G, Du J, Tang L, Xu J, Li J, et al. New role of graphene oxide as active hydrogen donor in the recyclable palladium nanoparticles catalyzed ullmann reaction in environmental friendly ionic liquid/supercritical carbon dioxide system. J Mater Chem 2011;21(10):3485-3494.

121. Monopoli A, Calo V, Ciminale F, Cotugno P, Angelici C, Cioffi $\mathrm{N}$, et al. Glucose as a Clean and Renewable Reductant in the PdNanoparticle-Catalyzed Reductive Homocoupling of Bromo- and Chloroarenes in Water. J Org Chem 2010;75(11):3908-3911.

122. Samim M, Kaushik NK, Maitra A. Effect of size of copper nanoparticles on its catalytic behaviour in Ullman reaction. Bull Mater Sci 2007;30:535-540.
123. Karimi B, Esfahani FK. Unexpected golden Ullmann reaction catalyzed by $\mathrm{Au}$ nanoparticles supported on periodic mesoporous organosilica (PMO). Chem Commun 2011;47:10452-10454.

124. Zhang W, Qi H, Li L, Wang X, Chen J, Peng K, et al. Hydrothermal Heck reaction catalyzed by Ni nanoparticles. Green Chem 2009;11(8):1194-1200.

125. Hajipour AR, Fatemeh RF, Khorsandi Z. Pd/Cu-free Heck and Sonogashira cross-coupling reaction by Co nanoparticles immobilized on magnetic chitosan as reusable catalyst. Green Chem 2017;19:1353-1361.

126. Calò V, Nacci A, Monopoli A, Fornaro A, Sabbatini L, Cioffi N, et al. Heck Reaction Catalyzed by Nanosized Palladium on Chitosan in Ionic Liquids. Organometallics 2004;23(22):5154-5158.

127. Senra JD, Malta LFB, da Costa MEHM, Michel RC, Aguiar LCS, Simas ABC, et al. Hydroxypropyl- $\alpha$-Cyclodextrin-Capped Palladium Nanoparticles: Active Scaffolds for Efficient Carbon-Carbon Bond Forming Cross-Couplings in Water. Adv Synth Catal 2009;351(14 15):2411-2422.

128. Nyangasi LO, Andala DM, Onindo CO, Jane C, Ngila JC, Makhubela BCE, et al. Preparation and Characterization of Pd Modified $\mathrm{TiO}_{2}$ Nanofiber Catalyst for Carbon-Carbon Coupling Heck Reaction. J Nanomat 2017;Article ID 8290892:1-13.

129. Ghorbani-Choghamarani A, Norouzi M. Suzuki, Stille and Heck crosscoupling reactions catalyzed by $\mathrm{Fe}_{3} \mathrm{O}_{4} @$ PTA-Pd as a recyclable and efficient nanocatalyst in green solvents. New J Chem 2016;40:6299-6307.

130. García CS, Uberman PM, Martín SE. An effective Pd nanocatalyst in aqueous media: stilbene synthesis by Mizoroki-Heck coupling reaction under microwave irradiation. Beilstein J Org Chem 2017;13:1717-1727.

131. Mitsudome T, Noujima A, Mikami Y, Mizugaki T, Jitsukawa K, Kaneda K, et al. Room-Temperature Deoxygenation of Epoxides with CO Catalyzed by Hydrotalcite-Supported Gold Nanoparticles in Water. Chem Eur J 2010;16(39):11818- 11821.

132. Moradi L, Ataei Z. Efficient and green pathway for one-pot synthesis of spirooxindoles in the presence of $\mathrm{CuO}$ nanoparticles. Green Chem Lett Rev 2017;10:380-386.

133. Noujima A, Mitsudome T, Mizugaki T, Jitsukawa K, Kaneda K. Gold Nanoparticle-Catalyzed Environmentally Benign Deoxygenation of Epoxides to Alkenes. Molecules 2011;16(10):8209-8227.

134. Lemhadri M, Doucet H, Santelli M. Alkynylation of Aryl Bromides with Propargylamines Catalyzed by a Palladium-Tetraphosphine Complex. Synthesis 2005;(8):1359-1367.

135. Gonzalez-Arellano C, Luque R, Macquarrie DJ. Microwave efficient S-arylation of thiols with aryl iodides using supported metal nanoparticles. Chem Commun 2009;(11):1410-1412.

136. Zhang W, Zeng Q, Zhang X, Tian Y, Yue Y, Guo Y, et al. Ligand-Free $\mathrm{CuO}$ Nanospindle Catalyzed Arylation of Heterocycle C-H Bonds. J Org Chem 2011;76(11):4741-4745.

137. Delample M, Villandier N, Douliez JP, Camy S, Condoret JS, Pouilloux Y, et al. Glycerol as a cheap, safe and sustainable solvent for the catalytic and regioselective $\beta, \beta$-diarylation of acrylates over palladium nanoparticles. Green Chem 2010;12(5):804-808.

138. Kaneda K, Mitsudome T, Mizugaki T, Jitsukawa K. Development of Heterogeneous Olympic Medal Metal Nanoparticle Catalysts for Environmentally Benign Molecular Transformations Based on the Surface Properties of Hydrotalcite. Molecules 2010;15:8988-9007.

139. Kegnaes S, Mielby J, Mentzel UV, Christensen CH, Riisager A. Formation of imines by selective gold-catalysed aerobic oxidative coupling of alcohols and amines under ambient conditions. Green Chem 2010;12(8):1437-1441.

140. Kim AY, Bae HS, Park S, Park KH. Silver Nanoparticle Catalyzed 
Selective Hydration of Nitriles to Amides in Water Under Neutral Conditions. Catal Lett 2011;141(5):685-690.

141. Polshettiwar V, Varma RS. Nanoparticle-Supported and Magnetically Recoverable Ruthenium Hydroxide Catalyst: Efficient Hydration of Nitriles to Amides in Aqueous Medium. Chem Eur J 2009; 15(7):1582-1586

142. Oliveira RL, Kiyohara PK, Rossi LM. Clean preparation of methyl esters in one-step oxidative esterification of primary alcohols catalyzed by supported gold nanoparticles. Green Chem 2009;11(9):1366-1370.
143. Lu H-Y, Yang S-H, Deng J, Zhang Z-H. Magnetic $\mathrm{Fe}_{3} \mathrm{O}_{4}$ Nanoparticles as New, Efficient, and Reusable Catalysts for the Synthesis of Quinoxalines in Water. Aust J Chem 2010;63(8):1290-1296.

144. Sadjadi S, Hekmatshoar R. Ultrasound-promoted greener synthesis of benzoheterocycle derivatives catalyzed by nanocrystalline copper(II) oxide. Ultrason Sonochem 2010;17(5):764-767.

145. Rahimizadeh M, Bakhtiarpoor Z, Eshghi H, Porde M, Rajabzadeh G. $\mathrm{TiO}_{2}$ nanoparticles: an efficient heterogeneous catalyst for synthesis of bis(indolyl)methanes under solvent-free conditions. Monatsh. Chem 2009;140(12):1465-1469. 